\title{
THE ROLE OF RELIGION AND ITS INFLUENCE ON CONFLICTS IN NIGERIA
}

ABSTRACT. At the very end of colonial rule, UK established Islam and Christianity in Nigeria as the two dominant religions with the middle belt region of Nigeria as the battle ground. Before their final departure, they secured and formed several ethnic and religious lines, which in the postcolonial era were used by political elites as a way to fight for state power. As such, on the basis of the abuse of political and religious elites, and on the basis of ethnic, religious and regional divisions, a deeply fragmented Nigeria as we know it today emerged. With colonial domination, sudden transitions, the power of society was destroyed to such an extent that it became incapable of regulating human passion. The situation is further heated by leading elites who manipulate religious identity, where as a result appears that the north of Nigeria, mostly Muslim, tends to Islamize the whole Nigeria, and the south, mostly Christian, strives to defend Christianity and the constitutional secularism of the state. In such a situation, religion, instead of calming passions and tensions, thanks to its leaders, opens the way to conflict, violence, extremism, and, finally, terrorism. The central understanding of the formation of the identity of religion and its transformation from conflict to violence is the rise of religious extremism throughout the country. Extremist groups show significant intolerance towards members of their own and other religions, react to social, economic and political crises of Nigerian politics, of course in religious terms, which later leads to conflicts. The integration of religion into Nigerian politics, which we can thank the colonial

1 boris.bursac89@gmail.com

This paper was submitted on September $25^{\text {th }}, 2021$ and accepted for publication at the meeting of the Editorial Board held on November $16^{\text {th }}, 2011$. 
rulers, is one of the leading problems and it is precisely this that stands behind religious violence and political instability in the country.

KEYWORDS: religion; fundamentalism; religious conflicts; ethno-religious identity; Nigeria.

\section{RELIGION AS A LEGITIMIZER OF POWER}

The author's previous work often characterizes religion as a multi-dimensional phenomenon, and it is extremely complex. It is simply because every religion declares its belief to be the only fair one and the only true one. Every religion has the goal of spreading the faith and protecting the religious identity, so as a logical sequence of events, a reflexive defensive attitude of the members of one religion appears. Usually in such moments, an individual or a group does everything in the name of God or by God's order, frequently using violence, which at some point produces an even more extreme form of action, religiously based terrorism. The role of religion in Nigeria is the role of the legitimizer of power. The ongoing conflicts of power and tensions over political leadership, where religion fuels political divisions, became clear in 2001 when a Christian was appointed as chairman of Jos or protests following the victory of presidential candidate Goodluck Jonathan. Such religious differences act as a fertile ground for political insults and feelings of exclusion, but also as domination of the opponent.

The amalgamation from 1914 made no sense and is often the foundation of the infamous relationship between the two leading regions of Nigeria. Northern Nigeria, which is divided into several states and three geopolitical blocs today, has remained largely Muslim. It used to be the center of the Sokoto Caliphate and today its Muslim population, especially those whose ancestors were part of the Caliphate, mostly look to the Middle East and therefore the wider Muslim world for solidarity and socio-political example. The South, an ethnically diverse region that today consists of many states, is largely Christian. The main sociopolitical influences are West and traditional African. These differences have been a source of political disagreement and suspicion between the two regions since colonial times, and if we add that each of the regions contains ethnic and religious minorities that have conflicts with ethnic and religious majorities it becomes clearer why political, sectarian crises and violent riots arise. 
In Nigeria's national politics, Christian concerns about Muslim domination over the national political space with the accompanying fear that more politically dominant Muslims will use their privileged influence to Islamize national institutions and impose Islamic Sharia law on non-Muslims date back to colonial times. Muslims, especially those from northern Nigeria, have tried to cope with what they consider to be tireless Westernization, and have sporadically sought refuge in parochial religious reforms.

Poor management of national resources and also the abuse of multi-ethnic and multi-religious coalitions of sequent rulers since independence have impoverished and denied opportunities to most Nigerians. As a result, religious rhetoric, which accuses members of other religious communities, and proposals for religious reform as solutions to society problems have found their way among the masses. The progress of socio-economic and political problems has deepened the social gap and triggered extremist and violent riots, such as the Islamist terrorist campaign of Boko Haram, which killed and maimed both Christians and Muslims. The adoption of the Sharia criminal justice system by the states of northern Nigeria, i.e., the Muslim majority between 2000 and 2002, was the culmination of a new politicization of religion. Once Sharia was introduced, it only intensified the fear of Christians that they would be persecuted and their freedoms guaranteed by the Nigerian constitution extinguished. Christian communities in the affected countries protested and their protests were fueled by the rhetoric of Christian politicians and leaders. Clashes broke out between the Christian and Muslim communities, during which thousands of individuals were killed, property destroyed and many thousands displaced. Sharia has been a turning point in Nigerian politics for decades. In 1978, when many Muslim delegates from northern Nigeria tried to extend sharia beyond family law at a constitutional conference, which led to a protest by Christian delegates. The compromise of the state with a majority or significant number of Muslims led to the establishment of Islamic courts, but use of Sharia law was limited to inheritance and family law. After that, religion became the main topic of national political debates, with each religious community becoming more defensive.

In northern Nigeria, conflicts between Muslim, largely ethnic Hausa and Fulani groups-and therefore the Christian and traditionalist communities-became everyday life. Christian ethnic groups in southern Nigeria have been drawn into these religious 
conflicts, and their members in the cities of northern Nigeria are often targeted by Muslim sectarians, while Muslims from northern Nigeria have sometimes been the target of revenge killings in southern Nigeria. The British colonial policy of indirect power, the system of divide and rule, created a sharp ethno-religious differentiation among Nigerians. Such British policies have made religion and ethnicity as prominent markers of identity in Nigeria and pushed exclusive identity politics into the political arena.

As a result of such events, in northern Nigeria, minority ethnic groups, largely Christian, have positioned themselves and they keep trying, in every way, to position themselves against the Muslim majority of Hausa-Fulani. Since colonization laid the foundations for the use of identity politics as a means of accessing political and economic resources, religious differences have further fueled political crises and opened the door to major national conflicts. A classic example is the civil war in which the federal government destroyed the Biafran separatist movement through pogroms, blockades, and starvation, and from this tragic episode of Nigerian history, religious animosities and even deeper divisions in the society grew.

After independence, religious and ethnic rhetoric, corruption, and incompetent leadership made the policy of religious and ethnic exclusivity more attractive. The root of this general division of society, that is, the ethnic-religious division of society, can again be attributed to the period of British colonial rule. To be precise, European missionaries sought to convert the central and southern regions of Nigeria to Christianity, while the northern ones were left intact. The reason for this colonial policy is explained by many authors such as Grams and Barnes by the fear of the British. In particular, the British did everything possible to prevent the emergence of an education system in the north that could jeopardize British control.

\section{EDUCATIONAL GAP}

Under the veil of protection of Islam, Lugard ${ }^{2}$ banned missionary activities as well as the establishment of schools in northern Nigeria, while at the same time, he approved colonial subsidies to some schools in Lagos, and even some Muslim ones. And the goal was obvious, to slow down the modernization of the more populous Islamic north and thus strengthen the British administration in that area. Thanks to this educational policy, the south, due to its 
earlier contact with Europeans, is at the forefront of Western education, which additionally opens the way to the already destabilizing inequalities of the Nigerian nation.

The country is not only divided educationally, religiously, and ethnically, but because of the different cultures of Christianity and Islam, people differ mentally and emotionally. The rift deepened further when wealthier Nigerians from the south sent their children to the UK for education. Regional disparities among people have grown, especially in terms of access to education and higher education. In the south, people were relatively 'enlightened' because they had access to education, which leads to concrete knowledge, while, for example in northern Nigeria, until 1936 they still used slaves. It was in such a deeply divided cultural environment that one of the leading Islamic organizations known as Boko Haram came on the scene with the desire to slow down the progress of pro-Western education, abolish the Nigerian government and establish sharia as the only valid law in all Nigerian territory. Religion has always had an important place in Nigeria and Nigerian politics; thanks to colonial rulers, the intensity of religious identity in Nigeria is considered one of the highest in the world (Paden, 2008).

Christian and Muslim identities were the foundation of religious differentiation and conflict, where Nigerian Muslims were much more likely to manifest or articulate religious identities than Christians. At the heart of this religious identity lies the deep distrust that each group feels towards the other. The majority of Christians in the country (62\%) say that they have little or no faith in people from other religions. A similar percentage of Muslims in Nigeria (61\%) say they trust people from other religions little or not at all. (Ruby \& Shah, 2007).

\section{ETHNO-RELIGIOUS IDENTITY}

What should be clear to us is that ethnicity and religion rarely act independently, instead they interact with each other, with the addition of other variables such as regional affiliation, in a complex and sometimes conflicting way. Precisely because of situations like

2 Sir John Frederick Lugard, was a British soldier, mercenary, explorer of Africa and colonial administrator, governor of Hong Kong (1907-1912), last governor of the protectorate of southern Nigeria (1912-1914), first high commissioner (1900-1906) and last governor (1912-1914) of the Protectorate of Northern Nigeria and the first Governor General of Nigeria (1914-1919). For his services in Nigeria in 1901, Lugard received the title of knight. 
this in Nigeria, the term ethno-religious identity was coined to encompass the tendency in which the boundary between ethnicity and religion merges in moments of conflict and violence. The central understanding of the formation of the identity of religion and its transformation from conflict to violence is the rise of religious extremism throughout the country. Extremists of all religions react to the social, economic and political crises of Nigerian politics, but in religious terms.

There is an emergence of fundamentalist movements that the author Karen Armstrong defines as " [...] defeated forms of spirituality that arose in response to perceived crises" (Bursać, 2018, pp. 1-9). These movements occur within religions-Christianity, Judaism, Islam-hence, this term is used for the most conservative wings within these religions, and today this term is usually used to mark a religious group that is intolerant and prone to violence. When we talk about Islamic fundamentalism, we must emphasize that it is under the influence of Christian fundamentalism, concept of jihad, or holy war, which is a classic proof of this statement. The same concept existed in Christianity only it was called the Crusade and it happened in another time period.

Apart from representing a spiritual struggle in Islam, we are increasingly seeing jihad in a much more dangerous form-a defensive-conquest war. So Islamic fundamentalists believe that they must return to the original Islam, because only in that way can there be a renewal of Muslim power and its further progress and strengthening. In addition, they believe that more Islamic-oriented states and of course societies must be formed. They base their claims primarily on historical oppression, occupation and injustice, for which they blame the "infidel West".

For these reasons, they are considered obliged, according to the defensive reflex mentioned previously, under the pretext of obligations under the Qur'an and Islamic Sharia law, to defend their religion and country.

"America and its allies are killing us en masse in Palestine, Chechnya, Kashmir and Iraq. Muslims have the right to retaliation. The 9/11 attacks were not aimed at women and children, the real targets were American symbols of military and just power. What the United States is going through today is insignificant compared to what we have been going through for decades. Our nation has been humiliated and despised for more than eighty years" (Esposito, 2008, pp. 69-73). 
That is why there is and will always be a conflict between East and West, between Islam and Christianity, just because both religions are extremely sensitive to so-called imperialist impositions.

The East believes that capitalism and liberal democracy are the greatest evils of today, while the West believes that authoritarian and illegitimate regimes should be stopped-and that difference creates conflicts. When we talk about Nigeria, both Christianity and Islam have contributed to the development of the country, but on the other hand, they have opened the way to conflicts and violence in the country. Islamic movements such as Maitastin, Izala, the Muslim Student Society, but also Christian movements such as the Pentecostals appeared. Both Muslim and Christian fundamentalists seek to expand their base of followers, through preaching and converting followers of other religions, often through stereotyping, preaching hatred, distortion, misrepresentation, and misinterpretation of different religious texts thus contributing to deepening differences and promoting intolerance among different religious groups. Since returning to democratic rule in 1999, after nearly three decades of military rule, ethno-religious conflicts have recurred frequently in Nigeria. While some of these conflicts were of lesser intensity and mere war of words, others erupted in the form of extreme and violent conflicts. Religious conflicts between Christians and Muslims in northern Nigeria as well as similar conflicts in other parts of the country over the years have left thousands of dead, wounded and also left many homeless. As we see every fundamentalism has a dose of religiosity in it, or we can say, every religion has its fundamentalists, so violence and conflict are nothing new, but their ability to incite new unrest, anger, mistrust, tension, and ultimately feelings of hostility is worrying. When we talk about religiously based extremism, we must also mention the term fundamentalism, which is often confused with extremism.

\section{FUNDAMENTALISM}

Fundamentalism is characterized by exceptional versatility, i.e., presence in all segments of human existence, starting with religion, politics, philosophy. In religion, fundamentalism is most often associated with Islam, to be more precise, it refers to Iran under Khomeini and later to many other Islamic countries. In politics, fundamentalism refers to the bearers of some political beliefs, of 
course derived from various alternative movements, that advocate and strive to achieve their radical demands (Bursać, 2018). In philosophy we remember Hans Albert who sees fundamentalism as any position that is opposed to 'fallibilism', the belief that every convention, assertion, or method could, in principle, be fallible in relation to significant situations (Kalekin \& Karlheinz, 2007).

Fundamentalism comes from the Latin word 'fundamentum' which translates as basis, hence a generally accepted definition according to which fundamentalism is a way of thinking in which certain principles are considered essential truths, which regardless of their content and connotation have inviolable authority. An interesting definition was given by Martin Rizebrot, who defines fundamentalism as an urban movement directed primarily against the disintegration of personalist, patriarchal notions of order and social relations and their replacement by depersonalized principles (Riesebrodt \& Reneau, 1998).

How fundamentalism is defined and interpreted depends to a large extent on one's perspective. From a modern, secular point of view, fundamentalists are reactionaries, they are a radical group of people who are trying in every way to take power into their own hands and bring society back to the dark age of oppression and intolerance. These fundamentalists are above all deceived, intimidating, and even evil. Proponents of modernization do not see themselves as these fundamentalists. Instead, they consider themselves good, reasonable people, lovers of freedom and human rights. Of course, from their own point of view, because they think more clearly and value empirical evidence and individual rights, the modernists can see that fundamentalists are wrong. On the other hand, fundamentalists and their sympathizers are wary, and they are afraid of the Western version of modernization and change, believing that it is precisely this modernism that destroys social communities, ties and values. Fundamentalists respond to these changes with a sharp "no" and when they do so out of their beliefs, modernists characterize them as fundamentalists and if they do so out of religious beliefs then they are religious or religious fundamentalists.

\section{RELIGIOUS FUNDAMENTALISM}

In order to get acquainted with the basics of fundamentalism, more precisely religious fundamentalism, we must rely on the historical context, which is very important for this topic. The root of funda- 
mentalism lies in American Protestantism in the so-called militant evangelism of the 1920s, more precisely in the debate that developed between the fundamentalists and of course the modernists of that time. The question that now arises if any fundamentalism is automatically religious, because it is often associated with religion. Certainly not.

The problem that arises here is very clear - fundamentalisms interfere, often political fundamentalism acts as a religious one, but in its essence, it is not, while on the other hand we have the option that religious fundamentalism very often seeks power and influence primarily in politics but also in the state. Therefore, we must always strive for a distinction - what is religious and what is political in this topic (Bursać, 2018). When we talk about religious fundamentalism, the first thing that comes to mind is Islam, in agreement with Simeunović (2009), who says that attributing to Islam the status of the only major religion that gives birth to fundamentalism, extremism and violence is unfair. Although fundamentalism is rightly most often mentioned in connection with Islam, there is not a single major religion, including very tolerant Buddhism, that has not been marked by its fundamentalism, and many of them by extremism (Brasher, 2001). So, as we see, fundamentalism is a complex and ambiguous phenomenon that is extremely difficult to define conceptually but also terminologically. Although all fundamentalist groups and movements differ in many ways, they are characterized by similarity. As part of a major Fundamentalist Project implemented by Marty and Appleby at the University of Chicago, they learned that there are nine features that are common to most religious fundamentalist movements. The first five are ideological and the remaining four are organizational features: (Marty \& Appleby, 1994).

- Reactivity towards the marginalization of religion

- Selectivity in terms of tradition and scriptures of religion

- Dualism - the Manichean struggle of good and evil

- Absolutism and infallibility

- Millenarianism and messianism

- Selected membership

- Sharp boundaries - towards the outside world

- Charismatic and authoritarian leadership

- Behavioral provisions - clearly prescribed lifestyles. 
To understand the impact of religion on the emergence of violence, extremism and terrorism, we need to clearly define what "religion" is and how it works in the context of this discussion. There is no generally accepted definition of religion, but religion can be generally described as a set of beliefs and views of the world in relation to a higher, holy being.

"For some, it is the kind of feeling (experience) that is not subject to logical or moral judgment. It is a "mystical" feeling of unity with infinite reality, the experience of infinity, the feeling of absolute dependence, the experience of everything in the world as God's work, the feeling of divinity in the soul, the experience of unity with God, encounter with divinity, the sacred and the like" (Tillich, 2009, p. 11).

It is this inaccuracy in the definition of religion that creates an obstacle in understanding the religious manifestation of political violence. From the sociological aspect, religion provides help in understanding oneself as well as one's own attitude towards others. In other words, it can be personal and collective, defining the difference between ' $I$ ' and 'you', as well as 'we' and 'they'. Jonathan Fox (2012) suggests that religion fulfills four important social functions:

- Providing a meaningful framework for understanding the world

- Providing rules and standards of conduct that link individual actions and goals into a meaningful framework

- Connecting individuals to a larger whole, sometimes providing formal institutions that help define and organize that whole

- Ability to legitimize certain actions and institutions

When considering what religion is and what role it plays in different societies, we must keep in mind that sacred texts are often the basis for religious beliefs, and the interpretation of sacred texts by members of a particular religious group will generally indicate that text as its foundation. Thus, all religions have their accepted dogma and belief system, which followers must accept without question and as such represent a latent source of conflict and can lead to inflexibility and intolerance towards other beliefs. After all, if it is the word of God, how can anyone question it. At the same time, script and dogma are often vague and open to interpretation. Therefore, in most cases, there is a conflict over the interpretation whose interpretation is more accurate, a conflict that cannot be 
resolved in the end because there is no arbitrator, which further leads to deeper conflicts.

Most members of different religions are moderate or self-satisfied, while on the other hand we have extremists who are motivated and want to express their interpretation of God's will, who contribute to the escalation of conflict because they often use radical measures as necessary to achieve their goals. Fundamentalists in religion are often driven by dissatisfaction with the modern as well as the marginalization of religion in modern society and do everything to bring religion back to the center. We have a classic example with Islamic fundamentalists who often link the spread of Western materialism to the rise of gambling, alcoholism and generally loose morals, so there is a need to 'purify' the society. As we see in almost every heterogeneous society, religious differences can serve as a source of potential conflict. Since individuals are often ignorant of other religions, there is a potential tension, but it does not necessarily mean that there will be a conflict. Religion is not essentially conflictual, but like ethnicity or race, religion serves as a very good way to distinguish oneself or one's group from another and may result in conflict. During various crises, whether they are social, political, economic, members of certain groups can in a short time perceive extremists as those who bring progress and peace. In such situations, group identities are even more strongly shaped, which reinforces the signal to extremists that a religion is threatened by another religion which is diametrically different. The feeling of oppression is then attributed to that current enemy, and radical expressions or interpretations come to light more and more, and then religion, which is a source of peace, thanks to the colonial division of society, along religious and ethnic lines, is a source of conflict and hostility.

\section{RELIGIOUS CONFLICTS IN NIGERIA}

Religious intolerance has been identified as the main source of religious conflicts in all multi-religious societies that exist in the history of mankind, so Nigeria is no exception. That religious intolerance, that hostility towards other religions, as well as the inability of religious adherents to harmonize between theories, as well as the different political philosophy of the leading religions in Nigeria are the leading causes of religious conflicts. This fact is sup- 
ported by ignorance of beliefs and teachings about another religion, as well as provocative actions that harm the religious sensibilities of people of other faiths, whether they are intentional or unintentional. Thus, religion in Nigeria has become a platform for socio-political articulation, and a means of spreading the already existing division in Nigeria.

For example, the agitation to create more states and local governments from the late 1960s to the early 1990s usually inspired Nigeria's various ethnic minorities to free themselves from either the Muslim or Christian leadership to which they belonged. This type of struggle often took on religious characteristics. The accelerated process of globalization and democratization, deepening economic crises and social inequality, reviving neoliberal ideology, trying to implement market reforms, diminishing state legitimacy and capacity have helped collapse the nation-building project in postcolonial Africa, especially Nigeria. Some authors state that the very nature of the federal government and the struggle for greater state powers contribute immensely to ethnic and religious conflicts. The relationship between religion and political life in Nigeria is not always obvious. There have been serious forms of violence between Christians and Muslims in the country. Some of them are related to long-term tensions between ethnic groups, while on the other hand we have new tensions caused by the movement or migration of the population outside their traditional homes. Thus, due to the colonial heritage, we have a 'mixing' of cultures but not their homogenization. More precisely, thanks to the colonial heritage, Nigerian society is polarized by religion, political parties, ethnicity, ideologies, social classes, and as such opens the way to antagonistic group relations. Despite the obvious and important role of religion in Nigerian society, it is necessary to analyze other alternative roots of political and other types of violence, because religion in Nigeria usually serves as a projector of strength, identity and unifier of different groups and is not a cause of conflict but a radicalizing factor. Therefore, religion is a reliable variable that with other factors that affects its final form and can lead to violence (Keddie, 1983). There is no society, whether primitive or civilized, without one form of religion or another. This religious inclination of man largely explains his life and even man's existence, which is often faced with some unpleasant experiences, that are the result of man's belief and existence. In modern society, one of the leading threats to human existence is the problem of terrorism, especially 
when it arises under the influence of religious radicalism. The Nigerian experience of what can be called terrorism in the name of religion is most clearly reflected in the actions of the terrorist organization known as Boko Haram. Due to the religious rift in which half of the population is Christian and half Muslim, as well as the large population, we can say that the Nigerian nation is more problematic than any other country in recent years in the sub-Saharan African region. In the last four decades in Nigeria, we can count more than twenty major religion-related crises that have shaken the nation.

Classic examples are the conflicts of the Maitatsin sect that began in the late 1970s in Maiduguri and spread to other parts of the region; and other religious crises, including some religious unrest, such as the case of the Ombatsa group in the state of Nasarawa and other inter-tribal wars or violence committed under the influence of religion, which left traces of tears and agony in many people. These crises in many cases begin as social, ethnic or political misunderstandings and eventually lead to violent interethnic and religious conflicts from which various extremist organizations emerge.

There has always been a history of religious violence, especially in the northern states of Nigeria. The genesis of these religious conflicts can be linked to 1986, that is, the decision of the then military government of Nigeria, according to which Nigeria became a member of the organization, better known as the Islamic Conference. Thanks to this development, two powerful groups emerged-Jamatul Nasril Islam (Society for the Support of Islam) and the Christian Association of Nigeria. With the strengthening of these groups, the country was thrown into unrest. On the one hand, the Christian Association of Nigeria appealed to all Christians to oppose the Islamization of the country. On the other hand, Jamatul Nasril Islam is sponsoring a campaign against the domination of the Christian minority over the Muslim majority. The situation further escalated after Nigeria returned to democracy in 1999, allowing all states in northern Nigeria to adopt Islamic Sharia law as their official state law.

The key question that should be asked is why the religious violence is gaining so much momentum in the north unlike other regions of Nigeria. The most impressive answer to this question was given by Ayuk and Emeka (2012), who blame the lack of education, profitable employment and mass poverty, which unfortunately have become a characteristic of the states in the north of Nigeria. 
The North becomes a base of idlers, who become leaders of fanaticism and arrogance. But we must not forget that unemployed restless young men are not only a characteristic of the north but also of the south of Nigeria. What we are interested in is why only in the north of Nigeria did youth without jobs take over religious terrorism and bloodshed as their calling. Perhaps the answer lies not in the present, but in the past of northern Nigeria (Ayuk \& Emeka, 2012). In northern Nigeria, there is a history of violent Islam that dates back to 1804 , more precisely to the jihad of Sheikh Usman dan Fodio, who then occupied the entire northern kingdom of Hausa and Ilorin.

Due to the lack of economic opportunities and the slow progress of education in this part of Nigeria, the achievements of Usman Dan Fodio are highly esteemed and respected and these young men may be trying to follow the same path that Dan Fodio followed centuries earlier. This path has two directions: it either leads to the emergence of extremist and terrorist organizations, or it becomes a process of leading the state, local self-government, the police, and socio-political life in general, covered by the veil of religion. Such a society, which is insufficiently educated, religiously divided, is the subject of constant conflicts that eventually lead to violence. Since independence, religion is an instrument of political manipulation and serves as one of the ways to approve as much state funds as possible and so gradually, overcomes the desire to ensure peace and full coexistence as well as national transformation in Nigeria. Interreligious relations have in most circumstances been limited by the acute level of religious hatred, intolerance, and violence since the end of the Cold War. Since the 1990s, Nigeria has become more and more divided along religious lines and open confrontations through religious messages have become fierce. Therefore, religion, which is emotionally driven, is often, at the slightest provocation, transformed from an instrument of peace building into an instrument of violence. These are some (not all) classic cases of religious conflicts in Nigeria that we encounter and that have been documented as religious in the literature: (Isaac, 2012; Jegede, 2019).

- Conflict among Muslims in Sagam, Ogun State over religious misunderstanding, July 1, 1999;

- Retaliation for the Sagam incident in Kano, July 22, 1999;

- Conflict between Christians and Muslims in the state of Kvara, December 20, 1999; 
- Riots over the introduction of Sharia in Kaduna, February 21-22 2000;

- Religious riots in Aba, February 28, 2000;

- Religious riot in Kano, October 12, 2001;

- Religious crisis in Kaduna, November 16, 2002;

- Religious conflict between Christians and Muslims in Numan town, June 08, 2004;

- Religious conflict between Christians and Muslims in Maiduguri, February 18, 2006;

- Religious violence between Muslims and Christians in the city of Jos, November 28, 2008;

- Muslim Fulani overnight attack on a Christian village Mazah, July 17, 2010;

- Islamists attack on Christians in Maikatako, January 2014; and

- Islamists attack on three churches in Borno, July 2014.

- Some authors have linked religious violence to the way preachers and their followers treat other religions (Stephen, 2006). While on the other hand we have authors who reject this claim and accuse infidel individuals of violent religious motives (Mamdani, 2002).

Be that as it may, it is obvious that religious rhetoric or propaganda has often been used to effectively gather support for establishing a collective consciousness for the work of some political ideas that may ultimately promote violence. Nnoli (1980) best described the power of religion. According to him, religious differences have a great potential for division among people. Throughout history, these differences have been the basis of tension, animosity, and even war. Many times, a certain fanaticism is associated with people of different religions, which negatively affects mutual trust when such relationships exist. This is because religion tends to define what constitutes appropriate social behavior. When this definition is networked with another, normal relationships become difficult (Nnoli, 1980).

CONCLUSION In Nigeria, religion, instead of keeping people together and promoting peace, did the exact opposite, alienating people and paving the way for conflict. However, some people in southwestern Nigeria, especially Yoruba, had an extremely small number of conflicts related to religion, because they invested all their differences in 
culture and perhaps because practically all people in this region profess Christianity. In any case, both Islam and Christianity increased their influence, thus changing the already established norms and value systems of the domicile population. Both religions came to these areas with diametrically different cultural orientations as a spectrum of their civilizations. Islam came with an Arab cultural orientation and civilization, just as Christianity came with a Western cultural orientation and civilization. Different cultural orientations as well as different civilizations defied the existence of autochthonous social and cultural value systems, which led to a serious collision, embodied in Huntington's famous work as the 'clash of civilizations' (Huntington, 2011). Historically, the history of human existence has been woven from the process of colonization and recolonization. More than two-thirds of countries in Africa, which Huntington classified as 'African civilization', have been colonized by Arab-Islamic or Western Christian civilizations in various historical epochs. There is ample evidence that in different periods of attempts to conquer African nation-states, the colonial conquerors encountered strong and fierce resistance. The resistance that existed then continues the struggle to protect indigenous civilization today and is often referred to as an act of fundamentalism. Africa, because of the obvious religiosity expressed by Africans, is often defined as 'notoriously religious', and as such has used religion in its original cultural formation to help people understand themselves, interpret the world, and pursue social collective goals. Thus, religion becomes an intertwined cultural fabric of life and a great driving force that governs the behavior, interaction and actions of people.

REFERENCES Ayuk, A. and Emeka, J. (2012). Curbing Multi-Dimensional Violence in Nigeria Society: Causes, Solutions and Methods of Solving this Trend. Journal of Emerging Trends in Educational Research and Policy Studies, Volume 3, 616-623.

Brasher, B. (2001). Encyclopedia of Fundamentalism. New York-London: Routledge.

Bursać, B. (2018). Verski fundamentalizam. FBIM Transactions, vol. 6 (2), 1-9.

Fox, J. (2012). An Introduction to Religion and Politics: Theory and Practice. Abingdon: Routledge Studies in Religion and Politics.

Isaac, S. (2012). Religious vViiolence in Nigeria: Causal Ddiagnoses and Sstrategic Rrecommendations to the Sstate and Rreligious Ccommunities. African Journal on Conflict Resolution, vol. 12(1), 107-112. 
Jegede, P. (2019). Implications of Religous Cconflicts of Peace, National Security and Development in Nigeria. Ilorin: Ilorin Journal of Religious Studies, vol. 9 (1), 53-70.

Kalekin, D. and Karlheinz, S. (2007). Radicals in Spite of Themselves: Ultra-Orthodox Women Working Outside the Haredi Community. Rotterdam: Sense Publishers.

Keddie, N. (1983). An Islamic Response to Imperialism. Berkeley: University of California Press.

Mamdani, M. (2002). Good Muslim, Bad Muslim: A Political Perspective on Culture and Terrorism. American Anthropologist, vol. 104, 766-775.

Marty, M. and Appleby, S. (1994). Fundamentalisms Observed (The Fundamentalism Project). Chicago: University of Chicago Press.

Nnoli, O. (1980). Ethnic Politics in Nigeria. The Journal of Modern African Studies, vol. 18 (4), 707-709.

Paden, J. (2008). Faith and Politics in Nigeria: Nigeria As a Pivotal State in the Muslim World. Washington D.C. United States Institute of Peace Press.

Riesebrodt, M. and Reneau, D. (1998). Pious Passion: The Emergence of Modern Fundamentalism in the United States and Iran. Berkeley: University of California Press.

Simeunović, D. (2009). Uvod u političku teoriju. Beograd: Institut za političke studije.

Stephen, E. (2006). The Mask of Anarchy Updated Edition: The Destruction of Liberia and the Religious Dimension of an African Civil War. New York: New York University Press.

Tillich, P. (2009). Dynamics of Faith. New York: Harper Collins Publishers.

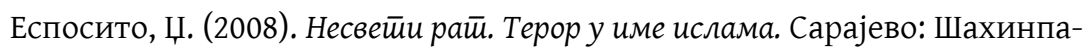
шић.

БОРИС Љ. БУРСАЋ

НАРОДНА СКУПШТИНА РЕПУБЛИКЕ СРБИЈЕ, БЕОГРАД

РЕЗИМЕ

УЛОГА РЕЛИГИЈЕ И ЊЕН УТИЦАЈ НА СУКОБЕ У НИГЕРИЈИ

Пред крај колонијалне владавине, Британија је успоставила ислам и хришћанство у Нигерији као две доминантне религије са средњим појасом као бојним тлом. Пре њиховог коначног одласка, осигурали су и оформили неколико етничких и религијских линија, које су у постколонијалној ери користиле политичким елитама као начин борбе за државну власт. Као таква, на 
темељима злоупотребе политичких и верских елита, етничким, верским и регионалним поделама настаје дубоко фрагментирана Нигерија какву данас познајемо. Колонијалном доминацијом, наглим транзицијама, моћ друштва је била срушена до те мере да је постало неспособно да регулише човекову страст. Ситуацију додатно загревају водеће елите које манипулишу религиозним идентитетом где се као резултат јавља да север Нигерије већином муслимански тежи исламизацији целе Нигерији, a југ већински хришћански тежи одбрани хришћанстава и уставне секуларности државе те религија уместо да смири страсти и тензије, захваљујући својим лидерима отвара пут конфликата, насиља екстремизма и на крају тероризма. Централно схватање формирања идентитета религије и његове трансформације из сукоба у насиље је пораст верског екстремизма у целој земљи. Екстремистичке групе показују значајну нетолеранцију према припадницима сопствене и других религија, реагују на социјалне, економске и политичке кризе нигеријске политике, наравно у верском погледу, што касније води у сукобе. Интеграција религије у нигеријску политику, што можемо захвалити колонијалним владарима, један је од водећих проблема и управо она стоји иза верског насиља и политичке нестабилности у земљи.

КљУчнЕ РЕчи: религија, фундаментализам, верски сукоби, етно-религијски идентитет, Нигерија.

Овај чланак је објављен и дистрибуира се под лиценцом Creative Commons Ауторство-Некомерцијално Међународна 4.0 (CC BY-NC 4.0 |

https://creativecommons.org/licenses/by-nc/4.0/).

This paper is published and distributed under the terms and conditions of the Creative Commons Attribution-NonCommercial International 4.0 licence (CC BY-NC 4.0 | https://creativecommons.org/licenses/by-nc/4.0/). 